\title{
Sustainable public procurement in a Brazilian higher education institution
}

\author{
Renata C. A. Mendonça ${ }^{1}$ (D) - Ivo V. Pedrosa ${ }^{2}$ (D) - Maria Amália O. A. Camara ${ }^{3}$
}

Received: 28 August 2019 / Accepted: 16 March 2021 / Published online: 5 April 2021

(c) The Author(s), under exclusive licence to Springer Nature B.V. 2021

\begin{abstract}
Public policies have required public agencies to adopt sustainable public procurement. It is necessary to understand the importance of the requirement for sustainable purchases to happen. Thus, this study aims to examine the main difficulties in adopting SPP at a public university in Brazil. To that end, research on the topic was carried out based on critical theory using qualitative methodology through a case study. Semi-structured interviews were conducted with three groups selected intentionally: requesters, purchasers and suppliers. Aspects related to the understanding of sustainability, SPP and the relationship between ethics and sustainability were analysed. The study revealed that the interviewees understand that ethics is directly related to the practice of sustainability, but it is a difficult issue because of its historical roots and changes in paradigms. Due to the complexity of the SPP theme, one of the main implementation difficulties mentioned by the interviewees was the lack of training. For suppliers, the understanding of sustainability was already consolidated, but it required agreement between being sustainable and economically viable for the company. Thus, this work sought to expose how those involved in SPP understood, refuted or validated sustainability issues in government procurement. Previous studies revealed the difficulties and conceptions of buyers, but we did not find research that investigated requesters and suppliers. It is hoped that this information will serve actions in favour of sustainable production and consumption and as a basis for other studies on sustainable public procurement.
\end{abstract}

Keywords Sustainability $\cdot$ Sustainable public procurement $\cdot$ Ethics $\cdot$ Case study Environmental education $\cdot$ Higher education

\section{Introduction}

The richest $10 \%$ in Brazil hold approximately $42 \%$ of the country's total income. This figure was pointed out by the Human Development Report of the United Nations Development Programme (UNDP, 2019), which recommends public policies to combat new and varied forms of inequality. In fact, the country has shown economic and social improvement over

Renata C. A. Mendonça

renata.calmeida@ufrpe.br

Extended author information available on the last page of the article 
some decades, but the historical roots of a colonized country with external dependence still present typical characteristics of under development. Thus, the problem in Brazil is not only generating income and increasing gross domestic product-GDP, but mainly social exclusion, lack of increasing quality of life and what is called nonsustainable development (Dolabela, 2004).

It is known that changes in paradigms and attitudes require a problematizing, contextualized education that awakens in society an awareness of the power of transformation that each citizen has. There is, therefore, an appreciation of the teaching of ethics in sustainability (Biedenweg et al. 2013; El-Zein et al. 2008; Howard, 2010; Rodriguez-Rad \& RamosHidalgo, 2018). In this context, SPP appears as a tool for sustainable practices, which can help in the challenging work of behaviour change and in improving the image of educational institutions. SPP consists of ensuring a purchase achieves good value for money, considering the entire life cycle, and generates benefits for the organization, the environment, society and the economy (Iclei, 2015). The major problem is that the consumer is rarely able to see the product life cycle beyond the stage of purchase and use (Cardoso, 2016).

However, little is known about how public sector organizations are responding to this encouragement or of the conditions that are most conducive to sustainable procurement (SP) (Brammer \& Walker, 2011). In Brazil, the few available studies investigate, almost always, the purchases made in federal teaching and research institutions (Couto \& Ribeiro, 2016). However, these works are focused on adding sustainability to the management purchasing sector (Alencastro et al. 2014a, 2014b; Couto \& Coelho, 2015; Couto \& Ribeiro, 2016; Ramos \& Santos, 2017; Warken et al. 2014). From these works, two questions emerged that instigated the present investigation: what is the relationship between the requirement for the adoption of Sustainable Public Contracts (SPP) and the understanding and evaluation of people involved with purchases (solicitors, buyers and suppliers), in a Brazilian public university? And how do these actors consider the relationship between ethics and sustainability? The Federal Rural University of Pernambuco is in the Northeast region of Brazil. It is 107 years old and is chosen in this study due to the tradition of carrying out projects and research in the agrarian, human and social sciences. Thus, the university seeks to contribute to overcoming socio-environmental problems and sustainable development.

Pacheco-Blanco and Bastante-Ceca (2016) encourage face-to-face interviews with Green Office managers to distinguish between the strengths, weaknesses and barriers that emerge implementing different GPP initiatives in various stages. On the other hand, Aleixo et al. (2018) suggest that surveys should include other stakeholders and their perceptions of implementing practices in the various dimensions of sustainability. For these reasons, this work seeks to understand SPP not only from purchasers but also from requesters and suppliers through face-to-face interviews about environmental, economic and social dimensions.

The goal of this study is to identify difficulties adopting SPP at the University of Pernambuco (UFRPE).

For this goal, the three specific objectives are as follows:

1. Identify interviewees' knowledge of sustainability;

2. Check the understanding of the relationship between ethics and sustainability; and

3. Investigate the difficulties in adopting sustainability criteria in bids. 
This work is divided into seven parts, including the introduction and conclusion. The second section deals with the literature review and then describes the selected case. The fourth section documents the materials and methods used, and then we discuss the results. In the sixth section, the political and managerial implications are reported and finally offer conclusions..

\section{Literature review}

In this section, the topics related to the research problem that were analysed to define the study objectives are presented. Table 1 shows the main concepts related to sustainable public procurement.

\subsection{Sustainable public procurement}

Public bodies are being encouraged to procure sustainably, to reduce their social and environmental footprint and to stimulate sustainability in the private sector (Brammer \& Walker, 2011). Therefore, in bidding, sustainable criteria are adopted, such as requesting stamps, certifications and environmental labels; favouring differentiated and simplified treatment for micro and small businesses; prioritizing recycled and recyclable products; preferring proposals that save natural resources and reduce gases; and purchasing products from family farms.

For a university to adopt green procurement, it is necessary to work on a sustainable human future, which requires a paradigm shift towards a systemic perspective emphasizing collaboration and cooperation (Cortese, 2003). The major difficulty in applying these changes is due to the change in culture. Shephard (2008) suggests that a central element of education for sustainability is a quest for affective learning outcomes for values, attitudes and behaviours. Is it necessary to have a holistic and interdisciplinary approach in which natural and social scientists work together to achieve wise paths for the use and exploitation of natural resources and respect their diversity (Sachs, 2009).

The university must break with traditional, functional and departmental structures, which produce rigidity in the decision-making structure (Batista \& Maldonado, 2008). There is a need for integration and sharing of information and knowledge among teachers, students and administrative technicians so that the institution can adapt to the dizzying changes and promote education in professional conduct to develop economic activities that include and do not exclude the population.

In this context, in the last decade, higher education institutions around the world have begun to consider sustainability as a key element in education, but this sustainable university process is incipient, and there are many obstacles to success of initiatives on the campus (Velazquez et al. 2005). We find in the literature studies that seek to understand complexities and positive actions on green procurement. Agyepong \& Nhamo (2017) investigate legislative provisions for green procurement in South Africa's metropolitan municipalities in the context of climate change and sustainable development. Testa et al. (2016a, 2016b) analyse the content of purchases in terms of green criteria by specifically focusing on building and construction. Tokbolat et al. (2019) explore the drivers of and barriers to the adoption of a sustainability paradigm in the construction in Kazakhstan. Brammer \& Walker (2011) address the gaps in our knowledge to inform policy development at the government and organization of all levels. 


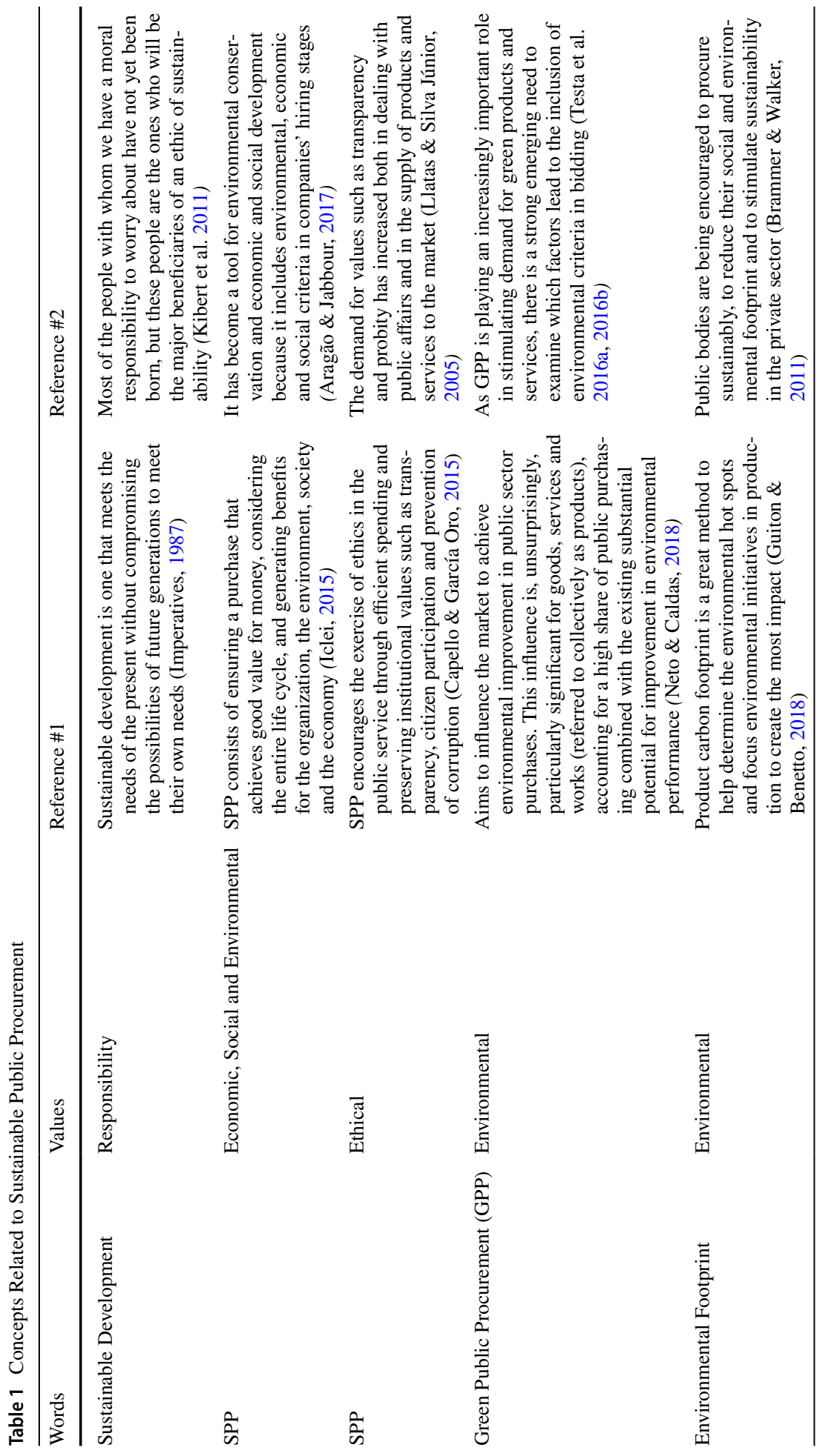




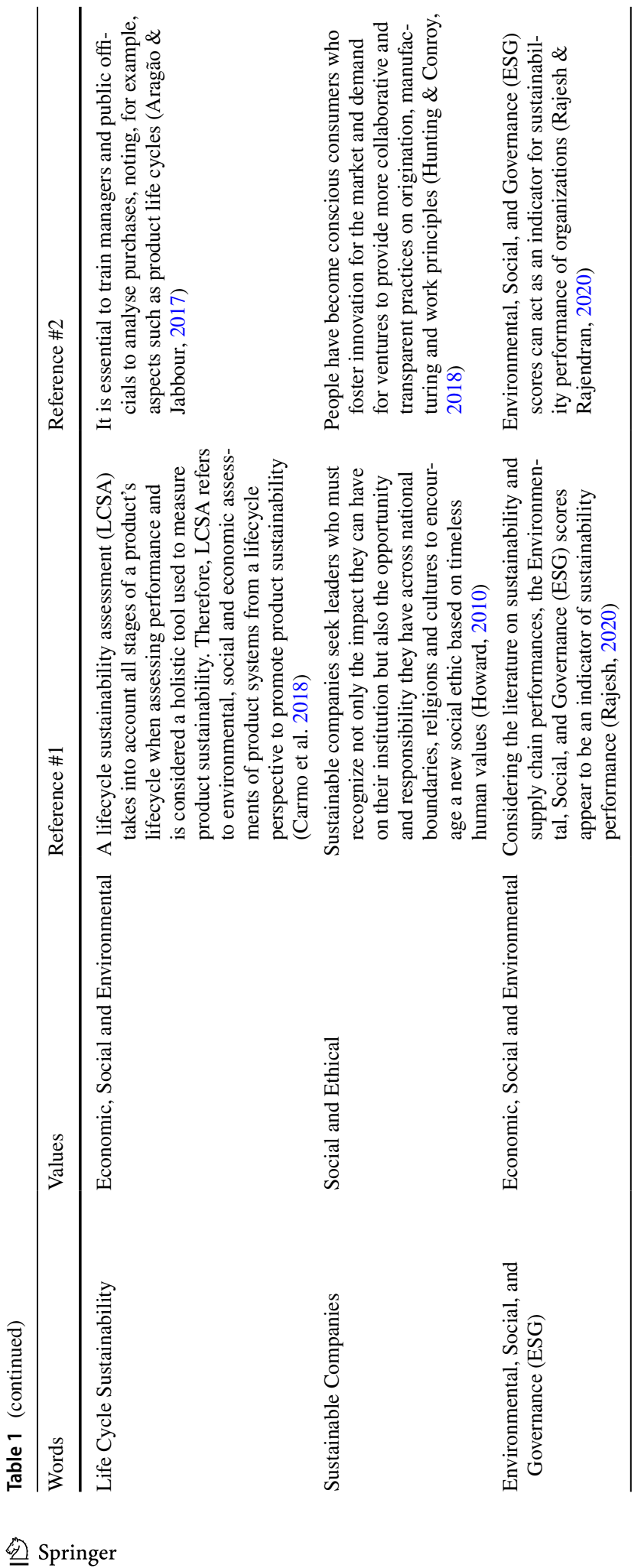


Thus, growing understanding of the importance of sustainability indicates that inadequate procurement practices undermine sustainable development and negatively impact economic growth. Therefore, developing countries need to recognize the importance of benchmarking to improve the procurement process (Raymond, 2008).

Public purchasing and contracting mobilizes resources of around 10\% of GDP, mobilizing important sectors of the economy that fit the expected demands in the bidding document (Biderman et al. 2008). It is essential to train managers and public officials to analyse purchases, noting, for example, aspects such as product life cycles (Aragão \& Jabbour, 2017). However, measuring the impact of sustainability on a public bidding process continues to be challenging since an objective definition of sustainability criteria is lacking (Lehtinen, 2012).

In the studies by Ahsan and Rahman (2017), the most critical challenges are the lack of legislation on green procurement, senior management support for green procurement, government incentives for green procurement and lack of financial support. Some of the minor important challenges are identifying ecological preferences in purchasing, understanding ecological policies, availability of green products and collaboration with the supplier. Aragão \& Jabbour (2017) identify lack of training and support from senior management, environmental culture, large bureaucracy and economic factors that are considered barriers and difficulties for the implementation of environmental procurement practices. In this research, we found these problems and asked for suggestions to help change this scenario.

By raising awareness of sustainability and providing opportunities to participate in it, universities can be powerful change agents with far-reaching impact (Emanuel \& Adams, 2011).

\subsection{Relationship between ethics and sustainability}

"If the global population actually reaches 9.6 billion by 2050, it would be necessary for the Earth to be three times as big to provide the natural resources needed to maintain the current way of living of mankind," according to the World Bank (ONU, 2017). This reality is clear in showing that the pressure on nonrenewable resources and environmental pollution would be such that the world economic system would necessarily collapse (Furtado, 1974). Studies report that greater consumption has not produced subjective well-being and suggests an alternative economic paradigm (Aydin, 2017; Hunting \& Conroy, 2018).

Editorial (1993) indicates that signs point to a crisis spiral that is manifested in the various sectors of human activity and reaches the very paradigm of our civilization. This civilization crisis is made visible, as it has happened in all other upheavals in human history, first of all, as an ethical crisis (Furtado, 1974). For La Taille et al. (2004), a true crisis of values is experienced. The anthropocentric paradigm, which has prevailed throughout modernity, is still present in our society. Editorial (1993) emphasizes that Brazil's sociocultural and political formation has consecrated inequality and instituted a patrimonialist state, favouring the elitist mentality. Boff (2006) informs that this crisis cannot be solved with only political and technical measures, but that a new ethical sensibility, new values, other forms of relationships with nature and new patterns of production and consumption will be necessary. The ethics of care address the entrenched assumptions in which our notion of moral decision-making rests. Ethical relationships of care are defined by attention and flexibility in relationships that challenge accepted hierarchies, competence and dependency (O'Hara 1998).

Most of the people with whom we have moral responsibility to worry about have not yet been born, but these people are the ones who will be the major beneficiaries of an 
ethic of sustainability (Kibert et al. 2011). Thus, one of the key words of ethical reflection is the word responsibility, that is, the duty to respond to the consequences of our actions. However, many companies disclose rules, or even codes of ethics, but do not comply with them (Faria, 2014). Sustainable companies seek leaders who must recognize not only the impact they can have on their institution but also the opportunity and responsibility they have across national boundaries, religions and cultures to encourage a new social ethic based on timeless human values (Howard, 2010). On the other hand, more people have become conscious consumers who foster innovation for the market and demand for a venture to provide more collaborative and transparent practices in origination, manufacturing and work (Hunting \& Conroy, 2018).

Therefore, the demand for values, such as transparency and probity, has increased both in dealing with public affairs and in the supply of products and services to the market (Llatas \& Silva Júnior, 2005). The system of sustainable public procurement becomes an important means of promoting sustainability, as it encourages the exercise of ethics in public service through efficient spending and preserving institutional values, such as transparency, citizen participation and prevention of corruption (Capello \& García Oro, 2015).

Through a better understanding of sustainability ethics, it becomes clear why the sustainability framework is an approach to tackling and solving the many difficult problems we face and why it is in fact the right approach, the right thing to do (Kibert et al. 2011). Thus, we can conceive sustainable development as a proposal that has in its horizon an ethical modernity, not only a technical modernity (Camargo \& Pinheiro, 2010). Table 1 shows the main concepts related to sustainable public procurement. With significant terms and values associated with those terms, two references are presented for each of them, allowing to contribute to highlighting the importance of related concepts.

\section{The case}

\subsection{UFRPE}

For this study, the Federal Rural University of Pernambuco was selected by location and availability of facilities and interviewed for data collection. It is 107 years old and has been chosen in this study due to its tradition of carrying out projects and research in the agrarian, human and social sciences. UFRPE has an academic and administrative infrastructure consisting of more than 1200 teachers, more than 1000 administrative technicians and more than 600 outsourced workers in addition to approximately 15,000 students (UFRPE, 2018).

The activities of UFRPE, as shown in Fig. 1, are carried out at the Campus Headquarters in Recife; in the four Academic Units of Garanhuns (UAG); Serra Talhada (UAST); Cabo de Santo Agostinho (UACSA), Distance Learning and Technology (UEADTec); in Dom Agostinho Ikas Agricultural College (CODAI); and in the advanced campuses. This structure represents a universe of 31 municipalities that directly have one or more actions of the university in the fields of teaching, research and extension (UFRPE, 2018). Through the advanced campuses, students, teachers and researchers develop lively experiences catering to local producers and the community in general. 


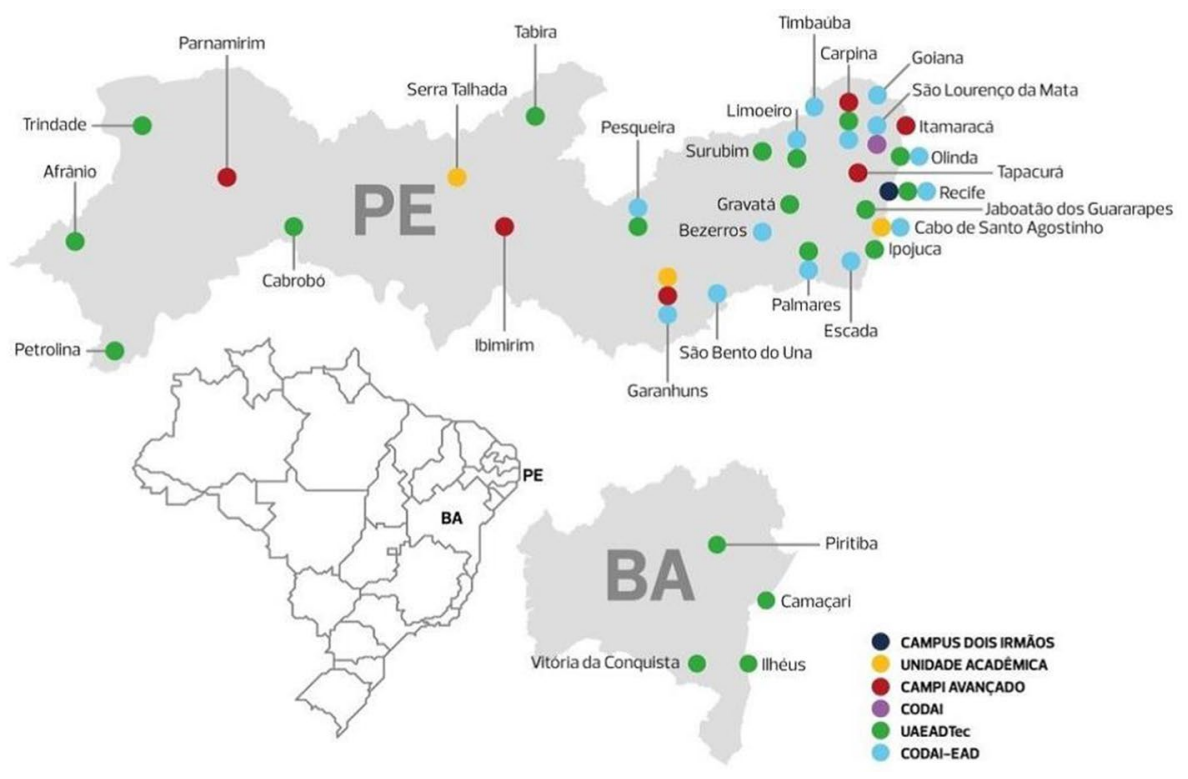

Fig. 1 UFRPE Regional Presence (UFRPE, 2018)

\subsection{Procurement process of UFRPE}

The opening of the procurement process begins with the demands and justification of the requester. The director of the requester's department is made aware and sends the request to the Dean of Administration (PROAD). If the demand is accepted, the process will be

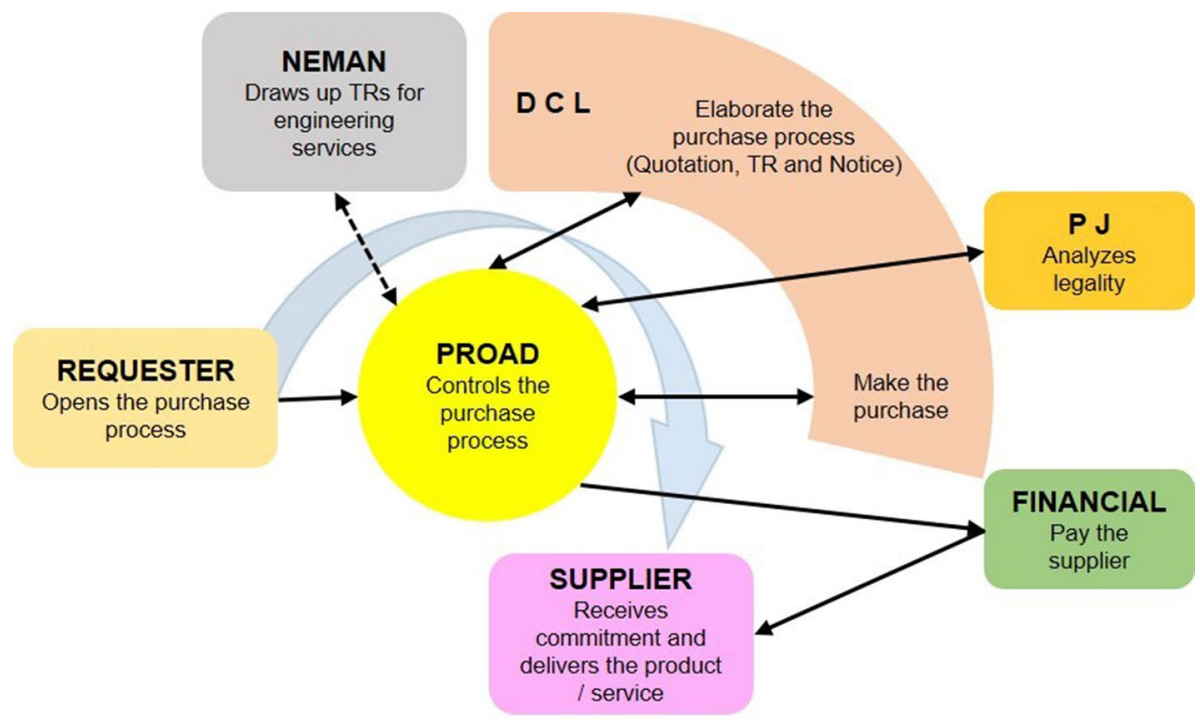

Fig. 2 Procurement Process at UFRPE 
forwarded to the Engineering and Environment Center (NEMAM) for engineering services with other requests forwarded to the Procurement and Bidding Department (DCL). At this moment, PROAD provides a budget allocation.

NEMAM elaborates the document that describes the service specifications, called the terms of reference. DCL, on the other hand, prepares the price survey, the terms of reference and the bidding notice for acquisitions. After the elaboration of such documents, the process is returned to PROAD and forwarded to the legal office (PJ), which verifies the legality of the purchasing process. The PJ returns the process with approval or guidance. PROAD sends the process back to DCL authorizing the opening of the bidding process, during which the purchase is made. Finalizing the bidding, the Pro-Rector of administration provides approval. Soon after, the financial commitment will be issued, which is sent to the supplier. The Supplier has a deadline for delivery of the service or product described in the terms of reference. After delivery, the invoice is sent to the financial officer to make the payment.

Thus, for the sustainable procurement process to be carried out, it is necessary for those involved to understand the importance of sustainability and that each has an important task to do. The requester must practice conscious consumption. It is important to ask the following: Do I truly need a purchase? Can I fix it instead of buying it? Do you have it in stock? How do I buy thinking about the three pillars of sustainability: economic, environmental and social? PROAD must carry out annual purchase planning to avoid shortages, loss of products and waste. The budget must be used for UFRPE's priority actions. The documents of the purchasing process (quotation, terms of reference, notice) must be well prepared and cannot be the task of just one sector. At that point, the requester must specify the need technically. The ideal situation would be to create a commission to indicate the sustainability specifications of the most requested items. Then, the environmental requirements of services can be adapted to the reality of the university and the region. They must search for suppliers that meet the requirements and listen to suppliers to understand the difficulties of the practice. A poorly prepared notice results in poor-quality services and acquisitions and wastes time and money (Fig. 2).

\section{Materials and methods}

Critical theory, which underlies the present research proposal (Freitag, 1994; Fleck, 2017), questions social reality seeking to understand both social relationships and the subjects and their place in these relationships (Faria, 2014). The methodological design was, therefore, planned in line with this perspective to contribute to a broader view of sustainability and public procurement in a more specific way.

For this reason, a methodological triangulation was carried out to raise the perspective of the subjects in their social relations. In addition to answers to an interview with the research participants, documents that regulate the bidding process for Brazilian public institutions were examined, and a systematic observation was conducted at the studied institution to verify the sustainable public procurement practices at the university (Fig. 3). 


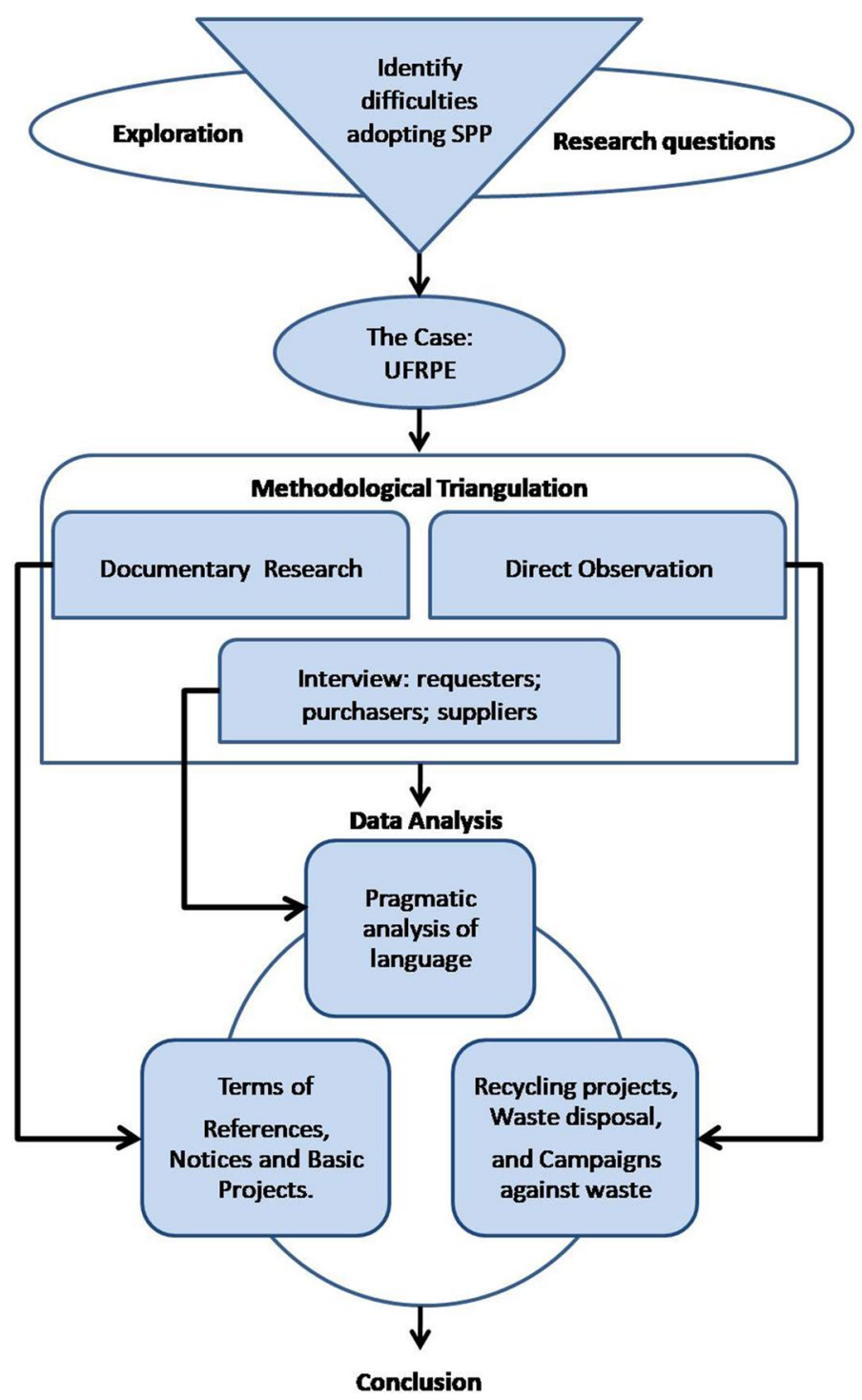

Fig. 3 Research Structure

\subsection{Field delimitation}

For this study, the Federal Rural University of Pernambuco was selected, with headquarters in the Metropolitan Region of Recife. The selection of the University followed some previously established criteria: location and availability of the management of the municipality to allow access to the facilities, employees and suppliers. Access to this information was authorized by the fact that the researcher is also a servant of the institution and ensures ethical rigor in the collection and analysis of the information. There was also an interest, on the part of the institution, that the research would result 
in actions aimed at improving public service and contributing to the sustainability of purchased goods, which, ultimately, represents the most rational way of dealing with public resources.

The investigation was characterized as a case study, in which there was a qualitative analysis of a set of nested information from a single public institution located in Recife. The research was structured to achieve its objectives. These objectives are presented in Table 2, along with a general characterization of the work.

The qualitative approach is justified in view of the objective of examining the main difficulties of adopting sustainable purchasing procedures in the institution, which is the focus of this investigation. These difficulties involve the participants' perspective on the phenomena that surround them. Therefore, it is a matter of investigating their experiences, points of view, opinions and meanings, which is how they subjectively perceive reality (Sampieri et al. 2013).

The strategy used in this work was a case study, which is normally used when the questions of interest are related to how and why, when the investigator has little control over events or when the research focus is related to a contemporary phenomenon in a natural context (Yin 2015; Cooper \& Schindler, 2016). In this work, a typical single case was represented by the reality of a federal public university. The objective was to examine the main difficulties in adopting sustainable public procurement at UFRPE.

In this work, triangulation of results was adopted because in a qualitative inquiry, data can offer greater wealth, breadth and depth if they come from different actors in the process, from various sources and from different forms of collection (Sampieri, Callado and Lucio 2013). For Yin (2015), any finding or conclusion from the case study is probably more convincing and accurate if it is based on different sources of information that converge. Data collection was performed based on triangulation of the following procedures: interviews, documentary research and direct observation. One of the most important sources of information for this case study was the interview, and the recorded audio certainly provided a more accurate interpretation of any interview than the researcher taking his own notes (Yin 2015).

\subsection{Participants}

There were three groups of participants: the requesters, who were people from different departments of UFRPE who most made acquisition demands. To compose this group, the Purchasing Department's employees were initially asked to indicate these people. Availability, interest in the topic and degree of involvement in the applicants' purchasers process were also considered. These interviewees had spent an average of nine years working at UFRPE, $60 \%$ were male, $100 \%$ had completed higher education, and $80 \%$ were people in charge.

The second group was the purchasers group, who were members of the departments that participate in the process of drafting bidding documents, such as the Procurement and Bidding Department (DCL), the Engineering and Environment Center (NEMAM), the Dean of Administration (PROAD) and the Department of General Administration (DAG). These respondents had worked for UFRPE for 13 years on average, $100 \%$ were male, $100 \%$ had completed higher education, and $83 \%$ were people in charge.

The third group was suppliers, who were selected from service providers that had the largest contracts in force with the University and the engineering companies that had mostly regularly or regular jobs at the University. The availability and degree of 


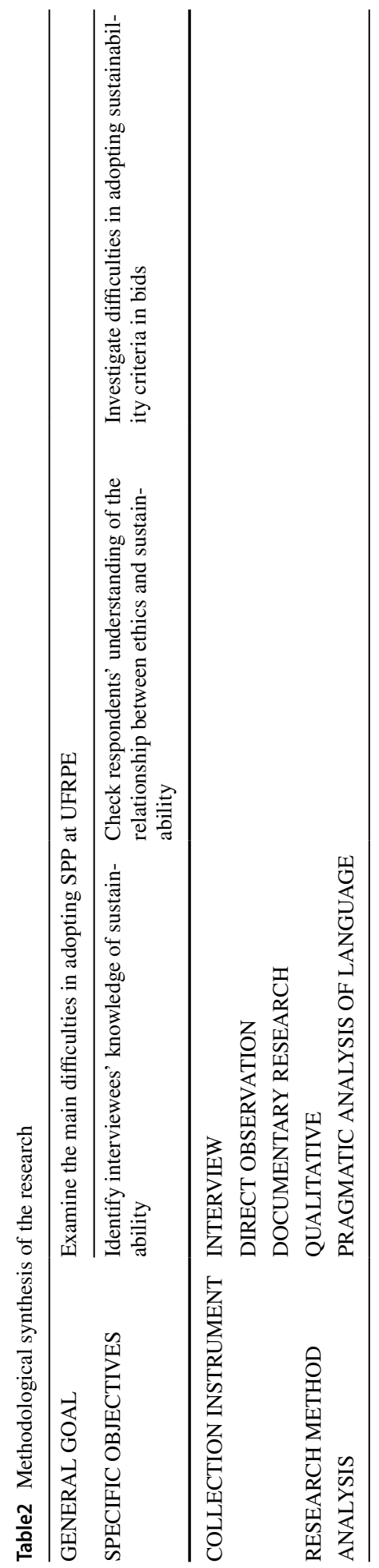




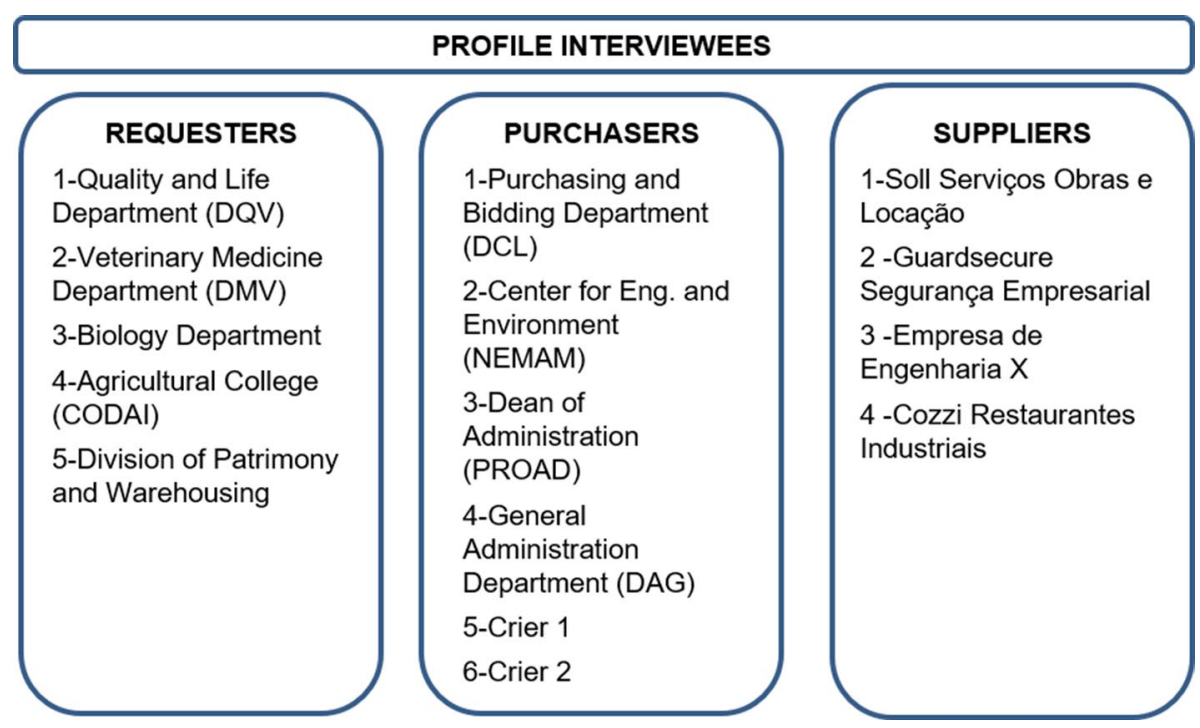

Fig. 4 Profile of the interviewees

involvement in the interviewees' purchasing process were also considered. The suppliers had an average of 10 years with their company, $80 \%$ were male, and $100 \%$ had completed higher education.

In total, 17 people were interviewed, but only 15 were considered because the responses to the interviews started to be repeated, and it was clear the criterion for saturation of results had been met. The interviews were conducted with requesters and buyers in the months of January and February 2018, which is the quietest period at the university due to student vacation. The supplier interviews, in turn, were carried out in the months of March and April 2018 according to the best availability of the interviewees (Fig. 4).

\subsection{Collection procedures}

As already mentioned, there were three data collection methods to allow for deeper analysis: (1) semi-structured interviews; (2) document research; and (3) direct observation of the institution's daily life in relation to sustainability. The semi-structured interviews with the three intentionally selected groups of requesters, purchasers and suppliers from UFRPE followed a previously prepared script, one for each group of respondents, to guide the fieldwork, without strictly limiting the search for information relevant to the understanding of the phenomenon. For the group of requesters, the questions were designed to investigate the interviewees' understanding of sustainability, the relationship between ethics and sustainability and the difficulties of adopting sustainable criteria in procurements.

The interviews went through a pretest stage, which gave an idea of the average time required for their performance and helped in the task of improving and prioritizing the questions. In advance of interviews with suppliers, analyses of documents and information about the companies were carried out. This information was obtained through internet 
search. These analyses served to add questions based on the specifics of each organization and other questions that were asked during the interviews.

The interviews were conducted in person with each participant, and before they started, the research objective, average time of the interview (average of half an hour, varying up to one hour), nonmandatory participation, nonmandatory response to all questions, possibility of clarification at any time about the questions, information on how to identify the participants, guarantee of confidentiality in the treatment of information and request for consent for recording were explained. Suppliers were asked to sign a consent form, of which the researcher provided a copy.

For document research, the second collection procedure, laws, decrees, resolutions, normative instructions, ordinances, bidding documents, basic projects and terms of reference were selected and analysed along with contracting guides already published on sustainable public procurement. The examination of these documents was intended to ascertain whether UFRPE was adopting these guidelines in the bidding processes.

The third procedure used in the collection of information was direct observation of institutional daily life with regard to procurements to register other aspects present at UFRPE that possibly enrich the information from previous steps. The phenomena occur in a specific reality, and the description of that reality could provide relevant clues for its understanding (Yin 2005). Thus, an attempt was made to register the process of purchasing sustainable items.

\subsection{Analysis procedure}

The pragmatic analysis of language, according to Mattos (2005), was the interpretative treatment chosen for this research. For the author, the interview analysis gains much from the approach to pragmatic language analysis, and the main reason in favour of this process is that the semi-structured interview is truly a special form of conversation. There is always an action meaning and a thematic meaning to the conversation.

The five phases proposed by the author were as follows: (1) interview transcripts; (2) analysis of the pragmatic meaning of the conversation, looking for the nuclear meaning of the response; (3) validation, which can be done with the interviewee or later by other sources (direct observation, documentary research, other people); (4) assembly of speech consolidation with translation of the nuclear meanings of the answers to a consolidation matrix; and (5) analysis of the sets, conclusive observations on sets and subsets of the statements. This phase is rich in arguments and inspiration. It is already possible to start partial analyses of the academic text (Mattos, 2005).

During analysis of the data, the structure of the relationships between the specific objectives and the categories of analysis was created so that the relationships between each specific theme became clearer and facilitated the analysis. This structuring was divided into three levels, which considered the specific objectives in the first level. In the second level, the topics or divisions of the specific objectives were considered, and in the third level, the divisions of the topics were considered. It is at this point in the analysis that the theoretical perspective most assists the researcher (Sampieri et al. 2013), supporting organizational choices to highlight the overlap in meaning that emerges from the participants' statements with the descriptions from the observations made and the understanding that emerge from the interpretation of documentary texts, in this case, from auxiliary laws and regulations. 


\section{Results and discussion}

This section is presented by data collection procedure: interviews, document research and direct observation. The interviews were divided by categories of analysis based on specific objectives. At the end, Table 3 shows the comparison of conceptual understanding of SPP among those interviewed, which contributes to an overview of the case study.

\subsection{Interviews}

\subsubsection{Interviewees' knowledge of sustainability}

The dominant concept of sustainability was about the correct use and reuse of materials according to Table 3. Environmental and economic pillars were more present in the interviews, but there were also mentions of social concerns on the part of some interviewees.

Social dimension: ...From the social point of view, when I define a method, a constructive system is one in which the work force is of local origin. We favour local development" (Purchase Dep. 3).

Economic dimension: Economically, I believe that in every bid we seek not the lowest value proposition, but the one with the best value. [...] (Purchase Dep.2).

Environmental dimension: ...Today, in the unit, $98 \%$ of the paper we use is recycled. We hardly use the white sheets. We do not buy wood from deforestation. We usually buy reforested wood and MDF ... (Purchase Dep.4).

Weisser (2017) relates the differences and perspectives of the three pillars of sustainability but defines a reciprocal relationship instead of one in opposition or competition. In addition, as companies do not only need to use socially and environmentally responsible behaviours, economic gains can be realized in the process (Gimenez et al. 2012).

Requester 5 mentioned the difficulties of adopting sustainability through a work project with microscopy that is making a difference in the university.

...I ended up seeing that we have dependencies. For example, equipment is expensive and dependent on electricity. It has a life span of years, but that is often shortened by misuse. [...]So what do we do? We recover it, take all the mechanical parts of the equipment, disassemble everything, sand paper, paint, reassemble and add a digital system for image capture, which is very cheap and efficient. Then, we transform it, and this system does not depend on conventional electrical energy...

In addition to the reuse of material that could be discarded, requester 5 adapted the microscope for greater efficiency.

...We only need power provided by a microcomputer, for example, because the system is very low voltage. If you turn it on to the microcomputer, the images are captured directly to the computer through photo or video, and you can connect the computer directly into the data show and give a lesson with a single piece of equipment. In a future proposal we are considering would make a partnership, an agreement, with the public schools and take this equipment there.

The shared use of equipment and laboratories could be encouraged, as is the case of Multi-User Laboratories, in which the same equipment must be used by different 


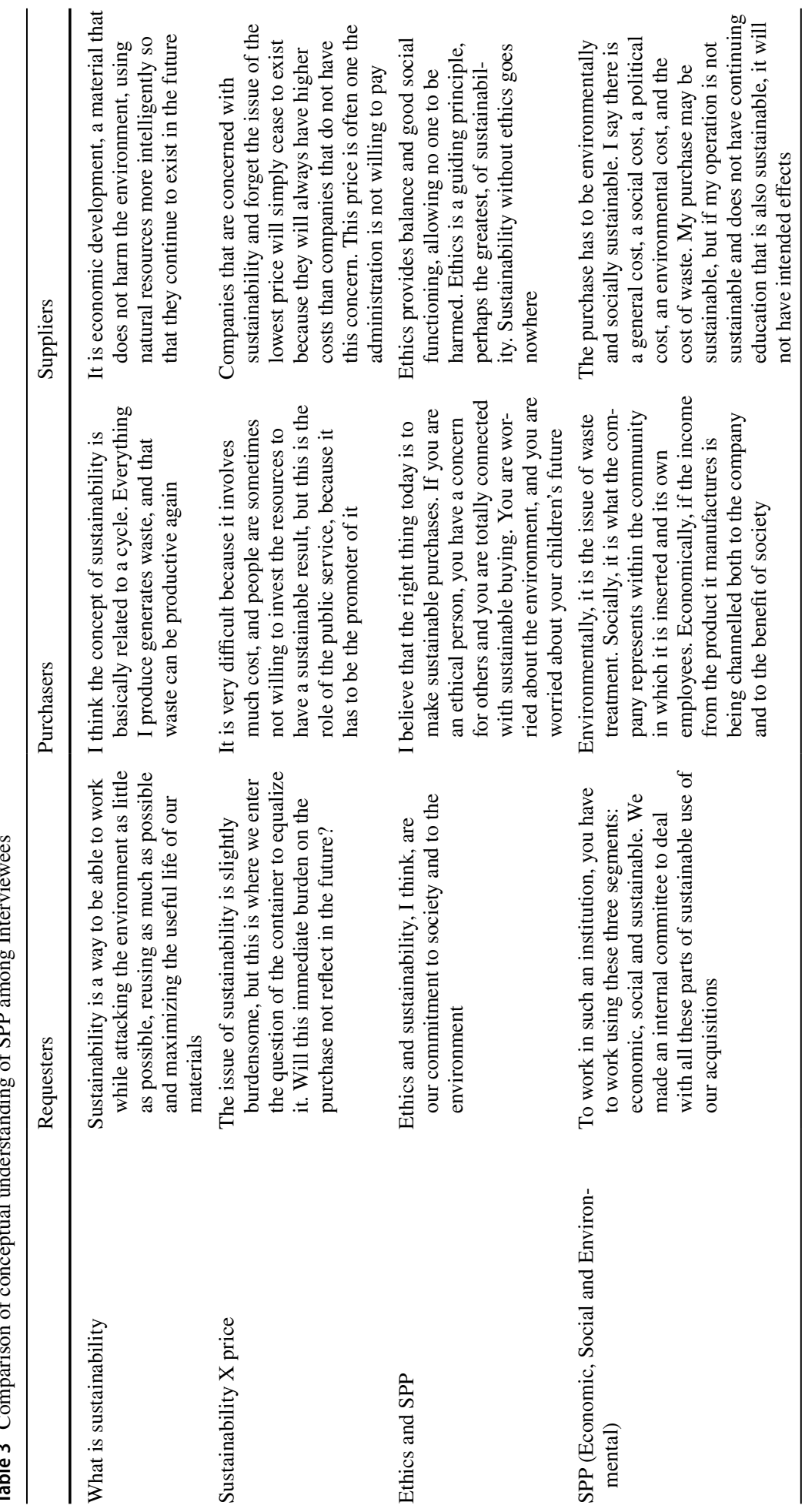




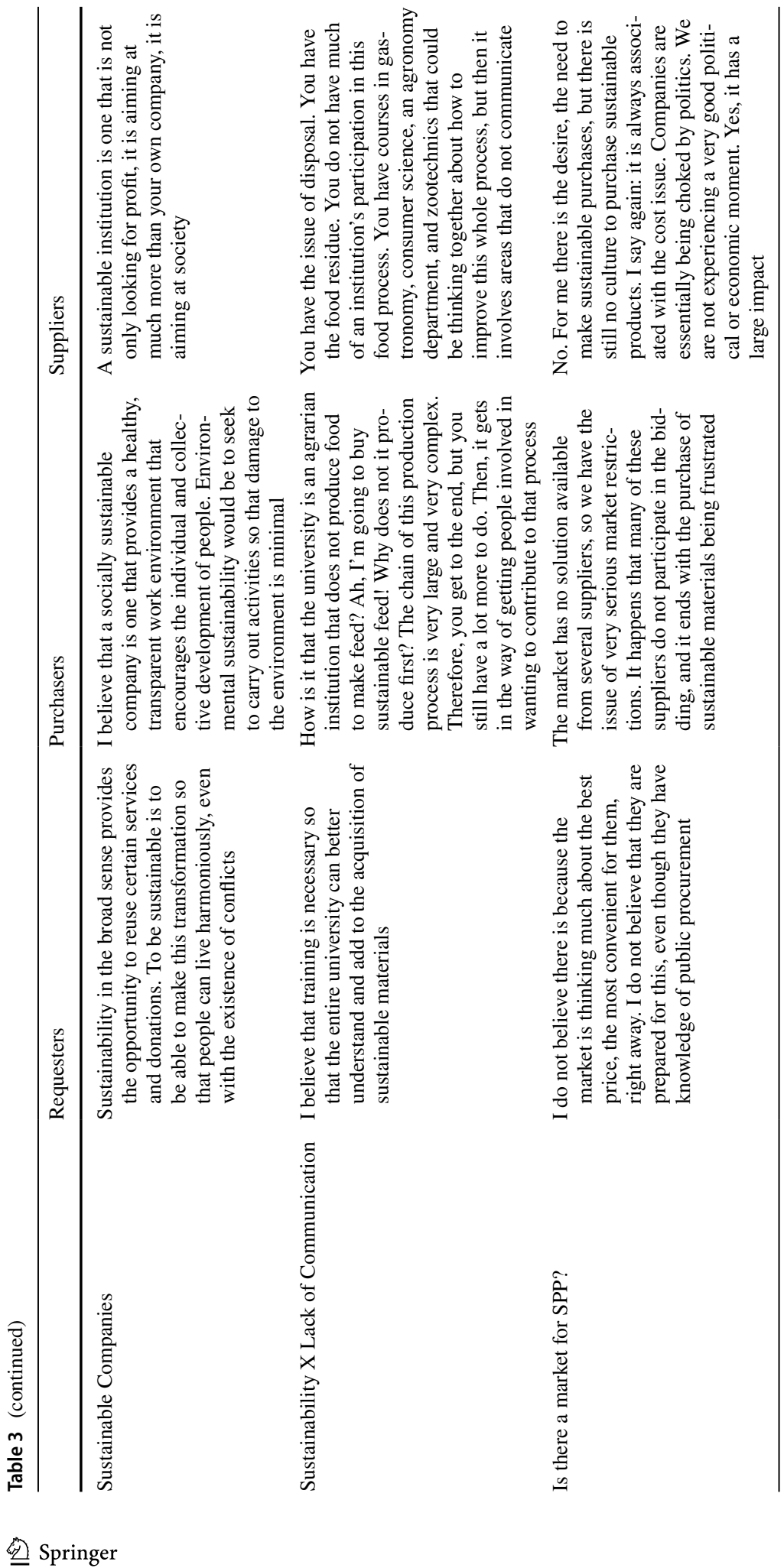


researchers. This step is a practical action of resource optimization and shared humanity (Howard, 2010).

Respondents linked to the Procurement Department consider sustainability to be broader and more complex. Some highlighted the product lifecycle concept.

... Sustainability is a very broad thing; it is not limited to a simple process of buying equipment or materials with sustainable criteria. You have to think about the question of the planet, and it is difficult because of the Culture for people to understand (Purchase Dep.6).

In this way, it is essential to train managers and public servants to critically analyse purchases noting, for example, aspects such as product life cycles (Aragão \& Jabbour, 2017). In the raw material procurement and logistics, the carbon emission is caused during the ordering, transporting and holding the procured items from various suppliers (Kaur \& Singh, 2019). So, details such as these should be considered in the product life cycle.

One of the interviewees commented on the importance of awareness of work to do what is described in the Sustainable Logistics Plan (SLP).

...It is no use buying sustainable energy equipment if the person does not rationally use that equipment. It is very complicated. It is very complex this issue of sustainability in the university because it involves, mainly, awareness, mobilization work, and personnel development. Simply putting that in a booklet will not solve the problem (Purchase Dep. 6).

These training suggestions are important, but the implementation of sustainability requires the participation of senior management and that the necessary procedures are incorporated into planning (Aragão \& Jabbour, 2017; Brammer \& Walker, 2011). Actions cannot be defined in isolation as they require the integration of several sectors. We can see this issue in the interviewees' statements about sustainability and lack of communication in Table3.

\subsubsection{Understanding the relationship between ethics and sustainability}

The question about the meaning of ethics was the one to which the respondents stopped to analyse and respond in a general way. They expressed doubts on their countenances. Requester 2 came to be moved.

... I even get emotional, because unfortunately I do not see ethics. That is why I think anyone who gives their interview finds it difficult, some more intense, like me, than others.

Another point highlighted in the interviews was the relation of ethics to the question of responsibility and respect got others.

... So I see ethics as the way you treat others in the same way you treat yourself and your loved ones (Purchase Dep. 6).

From Editorial (1993), the root of the current ethical crisis lies precisely in this tendency towards individualism, which is the mature fruit of modern subjectivity. Against this backdrop, a course on ethical principles related to sustainability is a useful and potentially critical component to prepare future professionals (Biedenweg et al. 2013). 
All interviewees agreed that sustainability was related to ethics, as we can see in one of the lines.

It certainly has a relationship. I even believe that sustainability, in any action, sustainable projects without ethics do not match (Requester 5).

On this subject, Requester 5 commented that he realizes that companies hire inexperienced people and do not invest in training. They offer many products but without concerns about meeting the real needs of the buyer.

... Their purpose is to sell, regardless of whether it will be well used or not. So, we meet a lot of company suppliers that come here to sell products, for example, molecular genetics, but they do not know about enzymes that will make the reactions we need ... (Requester 5).

It is true that consumers are attentive to the attitudes of companies and today, with digital media, it is common to protest by not buying in stores that do not act ethically. Therefore, companies that are driven by profit at the expense of people or the environment act with discredited ethics and put their reputation at risk (Howard, 2010).

Suppliers were asked whether it was common to find in bidding that other suppliers that offer products or services that are not compatible with the description and the reference price. All of them confirmed that it has already happened, and two vendors talked about the problem of unmanageable bidding.

What we see is that there are companies that present values that in our view are totally impracticable, but that during the bidding process, we cannot affirm that they will not comply with their contractual obligations ...(Supplier 1).

Faced with suppliers' responses to competitors' behaviours, it was asked whether they would have any suggestion for a requirement in a public notice to avoid this practice of unfeasible prices. Supplier 1's response was emphatic.

"But I do not see, in fact, something that can be introduced in the edict to prohibit this type of conduct. I think the solution to the conduct of these companies comes at a later time, at the time of inspection. They need to be aware that there is no tolerance, there is no future cover-up. They have to fulfil their obligations. That is, they are inspected and receive a penalty" (Supplier 1).

Since we read many corruption reports about public procurements in Brazil every day, the question arises as to the main causes that contribute to this reality. Many of the vendors spoke to the idea of the cultural problem in Brazil and of contemporary individualism.

Corruption is aimed only at bargaining. The fundamental concept is self-benefit to the detriment of the common benefit. Therefore, unfortunately, this origin of our colony, of exploration, brought this intrinsic idea of favouring (Supplier 2).

Supplier 4 offers hopeful words about transparency.

...I look favourably upon this issue of oversight bodies and inspection bodies to point out divergences with reality. I think everyone is, let us say, shocked by the Brazilian reality, with these cartels of companies, the construction companies, but I think that, as a Brazilian, we should look into the future with better eyes because that will improve transparency.

Thus, the challenges of today's society call for courageous business leaders to master the art of being human and to master the art of managing a successful company geared 
towards serving society and promoting a new global ethic in its sphere of influence (Howard, 2010).

\subsubsection{Difficulties in adopting sustainability criteria in bids}

The main complaints about difficulties when adopting sustainable criteria in bids were lack of recourse, clash between suppliers and availability in the market.

... If you put in sustainability criteria, say that a company did not have this product, it wants to win the bid, but it does not have the sustainable product, and then says that it is being biased, hurting the criterion of competitiveness, and more wear and tear on this part of the bid. (Purchase Dep. 2).

...The resources are very limited so we cannot use many sustainable criteria. (Purchase Dep.3).

To reduce this problem, when quoting the service or material for a sustainable item, it is necessary to seek the real value and the correct specifications and options in the market. As demand for sustainable solutions increases, the price tends to fall. For the Purchasing Department, there are few or no businesses prepared to meet SPP because there is little demand, lack of a sustainable culture and lack of incentives from the federal government. Government incentive or pressure on public sector institutions and managerial commitment to sustainable practices are required. Without funding and training for the procurement team, demotivation and weak employee competencies occur. Where the procurement team is not interested sustainable products, suppliers also do not increase their capacity. They do not invest in sustainable products because there is no demand (Zaidi et al. 2019).

It is still small, because it is not a practice of the majority. In contrast, it is a small part of the public service ... (Purchase Dep.1).

Purchase Dep.5 points to the federal government's lack of incentives to develop a sustainable market.

...The practice of sustainability within companies is more a requirement of the market itself than a requirement of the government. It is the public sector going along with the demands of the consumer market (Purchase Dep. 5).

Suppliers admit that there is no market prepared for SPP, or when it exists it is a small share and usually large companies. Alack of culture for sustainability, unfavourable economic policies, and lack of alignment between public administration and entrepreneurs are the factors reported by suppliers.

"For me the market is somewhat chaotic. Is there a ready market? Yes, there are companies that are prepared, but there are also adventurers, companies that do not want to know how they will reach that goal, which is to raise profit. The larger the company, the greater concern about this service, but the smaller it is, the more it sees only the purpose" (Supplier 2).

I do not think we're ready today. I do not think so. There has to be a positive agenda, between entrepreneurs and public administration, to put this on the agenda and to truly address what is possible, what is sustainable, what is the priority, what are we going to do first, what is the first phase of the project, what are the points we have in each phase, who will do each phase, how will we monitor each phase and what are the evolutions of that phase of the project ... ( Supplier 4). 
This interviewee also indicates a need for alignment between public administration and entrepreneurs.

The entrepreneur has to fulfil his social mission, but the administration also needs

to fulfil its practical function. They have to be aligned: the social duty of the entre-

preneur with the practicality of the administration to find solutions for this agenda.

Ahsan \& Rahman (2017) agree on the most critical challenges, which are the lack of legislation on green procurement, senior management support for green procurement, and government incentives for green purchasing.

Thus, a great portion of SC barriers is related to economic aspects, which are followed by government as well as awareness and education-related barriers (Tokbolat et al. 2019). These deficiencies can be minimized with events conducted by public sector organizations to better understand suppliers (Walker \& Brammer, 2012). Ahmed et al. (2020) recommended that a tax incentive initiative should be offered along with a sustainable development mechanism, and an awareness program to guide private investors and entrepreneurs.

\subsubsection{Investigate difficulties in adopting sustainability criteria in bids}

Two questions were asked of the servers and one of the vendors to investigate aspects to the third specific objective: what are the important points that the public servant should observe to ensure a good public purchase? What suggestions would you give to foster sustainable public procurement at UFRPE? More than one reply about a good purchase indicates the public servant's commitment to public affairs, which is not simply to obtain the least expensive items but also to have awareness of the end result of their work.

Purchase Dep. 6 reinforces the idea of the importance that the public servant should see in the work he does on this commitment.

It is important to note that this is public money and that he has to choose the best applicant for public resources. So, he should treat it the same way he treats it when he is going to do it for himself (Dep. Purchases 6).

Thus, researchers recommend that firms make strategic use of moral commitment as a form of corporate governance to serve stakeholders (Barron \& Chou, 2017).

Creating good specifications of the object and a price survey consistent with the good and market value were also cited as affecting good public purchases.

Supply of what was demanded, the description and the best price. When I describe the product with higher quality, greater precision, not directing the brand, but giving quality to the product requiring environmental certifications, or not, I have a product closer to quality (Purchase Dep. 1).

For suggestions to foster SPP, both requesters and the purchasing department emphasized capacity-building (including suppliers) for culture change, planning and commissioning to determine sustainable criteria.

I believe it is a matter of investing in training the public servants, and then after this training, a greater charge on the part of the Pro-Rectors, for instance, to set up a sustainability committee inside the university (Purchase Dep. 4). 
By raising awareness and providing opportunities for sustainability, universities can be powerful change agents with far-reaching impact (Emanuel \& Adams, 2011). Suppliers indicated practices that can improve the bidding process and service delivery.

My suggestion to foster would be to bring it more explicitly in the notice instruments so that you can first check whether that requirement had its costs effectively anticipated, and perhaps more importantly, that oversight accompanies this execution. This

I think is the great point, if you bring the obligation but do not require it, it becomes useless. (Supplier 1).

Relevant suggestions were made by respondents and can be applied in institutions that intend to or already adopt public procurement. Attitudinal change training, improved communication between servers and suppliers and formation of study groups to standardize sustainable criteria and requirements in bidding documents were some of the suggestions. We found other important points presented by authors that must be considered to increase the performance of sustainability of an institution;

The study by Yang et al. (2020) indicates that Green supply chain management (GSCM) and green information system (GIS) are two important pillars of green innovation. The authors suggest for those who come up with good ideas and even implement them in work, there will be rewards in forms of bonus and promotion. Over time, this cultivates an organizational culture that encourages green innovation through open communication and collaboration. Whatever framework emerges needs to be flexible, to recognize that embracing SP is a developmental journey, and should seek to engage stakeholders, both internal (all staff) and external (i.e. suppliers) (Leal Filho et al. 2019).

Another important point is to have indexes that can measure the performance of sustainability. Rajesh (2020) considers that in literature on sustainability and supply chain performances, the Environmental, Social, and Governance (ESG) scores appear to be an indicator of sustainability performances. In his study, it was observed from the results of the analysis that the resource use score of resources, the Environmental Innovation score and the Corporate Social Responsibility (CSR) strategy score emerge as the most important indicators contributing to Environmental, Social and Governance performances of Indian firms. Therefore, managers can study in detail the moderating effects of companies' individual ESG performances to see the extent to which these effects can improve the overall sustainability performance of companies (Rajesh \& Rajendran, 2020).

Still on Corporate Social Responsibility (CSR), the theory of legitimacy suggests that firms disclose environmental information to provide evidence of compliance with their obligations under the implicit contract they have entered with society, which is necessary for the firm's position to be legitimized (Pedron et al. 2020). Therefore, transparency of information, dialogue between those involved in the purchase process, measurable sustainability indices and concern with the supply chain are the relevant points discussed by these authors.

\subsection{Document research}

In 2017, UFRPE held 120 tenders, 97 of which were valid. The $19 \%$ of invalid bids were for different reasons: deserted bidding (for which no competitors appeared), cancelled, failed or cancelled during approval or acceptance. Of this total, the traditional auction was the most frequently used. To verify whether UFRPE's purchasing processes in 2017 are in accordance with Normative Instruction SLTI/MPOG No. 1, of January 19, 2010 
and Law No. 8.666, of June 21, 1993, regarding the criteria for sustainability, 40\% of bids for each modality were selected with different contracts or purchase objects. During data analysis, we confirmed what many of the interviewees had commented, such as that in information in the engineering service notices, sustainable criteria are more present and applied as standards. Thus, the $40 \%$ of the bids examined seemed sufficient to ascertain the information obtained from the interviewees. Table 4 highlights and consolidates the existing sustainability items in terms of references, notices and basic projects.

In analysing the documents, it was observed that there were no uniformity and no consistency in sustainable criteria, except in the public notices and basic engineering projects, but still in an incipient way. These data agree with the report from Purchasing Dep. 6, which also commented on the difficulties of adopting sustainable criteria in services.

In the case of construction, as it is the most planned work, then, obligatorily, he has to observe the sustainable items, but still I think that few resources are used that could be used much more. If the cost impacts the price, then it ends up giving up some sustainability to make the construction feasible.

For sustainable descriptions for acquisitions, the interviewee from Purchasing Dep. 6 indicated the following:

For materials, it is punctual, it depends on the construction of that process and who is building it because today there is no guidance from the institution.

Normative Instruction SLTI/MPOG $\mathrm{n}^{\circ}$ 1, of January 19, 2010, in art. 1, determines that the specifications for the acquisition of goods, contracting for services and works must contain criteria for environmental sustainability for extraction or manufacturing processes, use and disposal of products and raw materials. Soon after, it says that the instrument must formulate requirements of an environmental nature so as not to lose competitiveness. While art. 5 lists some optional criteria for the acquisition of goods, art. 4 requires that the basic or executive project be elaborated with a view towards saving on maintenance and operationalization of the building, reducing energy and water consumption and using technologies and materials that reduce environmental impacts. In terms of reference and notices from UFRPE, it was observed that there was greater concern for the insertion of sustainability criteria in construction services than in other procurements. The analysis of institutional documents for bidding, therefore, reveals aspects that corroborate what the interviewees said.

Suppliers also reported what UFRPE has required in relation to contracts. Supplier 4, for example, cites some new requirements and some difficulties in practice.

In this new contract, some new requirements were made that aim to implement the sustainable agenda of the rural university in new contracts. The two main points that I saw are the acquisition of a glass or porcelain cup to replace disposable ones. This is an obligation of ours that we encounter in the infrastructure to store 4 thousand glasses, so I need an extension of the restaurant. One thing is the glass cup we have in our house, 10 units, 12 units that we wash. The intention is very good, to decrease the disposable, but what is the risk? Very high.

The normative instructions and laws determine the adoption of sustainable criteria in bidding, but as we can see in supplier's statement 4, these must be well evaluated considering compliance with the suppliers and UFRPE itself. 
Table 4 UFRPE bidding and sustainability criteria

\begin{tabular}{|c|c|}
\hline Bidding Mode (2017) & Sustainable description in the Notice \\
\hline $\begin{array}{l}\text { Auction } 5,20,24,25,28,30,36,38,48 \\
\quad 49,61,64,77,79,99,102,104,106 \\
108,109\end{array}$ & $\begin{array}{l}\text { Exclusive participation in micro, small and cooperative com- } \\
\text { panies covered by art. } 34 \text { of Law No. 11,488, of } 2007\end{array}$ \\
\hline Auction 7 & $\begin{array}{l}\text { Adopt sustainability criteria in the execution of services as } \\
\text { determined by item 9.1.47. Rationalization of water, energy, } \\
\text { waste separation, and substitution of toxic substances }\end{array}$ \\
\hline Auction 11 & Model of environmental sustainability declaration \\
\hline Auction 17 & $\begin{array}{l}\text { The goods must be supplied according to the sustainability } \\
\text { criteria established in art. 5, from IN MPOG } \mathrm{n}^{\circ} 01 \text {, of Janu- } \\
\text { ary } 19,2010 \text { (item } 3.1 \text { ) }\end{array}$ \\
\hline Auction 41 & $\begin{array}{l}\text { The suctioned waste will be transported to its final destination } \\
\text { in a location authorized by an environmental agency and in } \\
\text { compliance with all current regulations }\end{array}$ \\
\hline Auction 46 & $\begin{array}{l}\text { Classification of the Conpet seal: A. The correct type would } \\
\text { be a Procel A seal and was not required for all items. Eco- } \\
\text { logical refrigerant gas (item 41) }\end{array}$ \\
\hline Auction 53 & PROCEL seal \\
\hline Auction 86 & Model of an Environmental Sustainability Declaration \\
\hline Auction 91 & Type "A" energy efficiency seal for ecological refrigerant gas \\
\hline Competition $\mathrm{n}^{\circ} 02$ & $\begin{array}{l}\text { Declaration that it does not use direct or indirect labour of } \\
\text { minors under } 18 \text { (eighteen) years old at night, in danger- } \\
\text { ous or unhealthy work and any work for minors under } 16 \\
\text { (sixteen) years, except as an apprentice from } 14 \text { (fourteen) } \\
\text { years pursuant to Law No. } 9,854 \text {, of } 1999\end{array}$ \\
\hline Price Socket $n^{\circ} 03$ & $\begin{array}{l}\text { Proof of Enrolment in the Federal Technical Register of } \\
\text { Potentially Polluting Activities or Users of Environmental } \\
\text { Resources, accompanied by the respective valid Certificate } \\
\text { of Regularity pursuant to Article } 17 \text {, item II, of Law No. } \\
6,938 \text {, of } 1981 \text {, and Normative Instruction IBAMA No. } \\
\text { 06, of } 03 / 15 / 2013 \text {, and related legislation for the exercise } \\
\text { of civil works activity, classified as potentially polluting or } \\
\text { using environmental resources }\end{array}$ \\
\hline Auction/SRP n ${ }^{\circ} 18$ IRP n $^{\circ} 004$ & $\begin{array}{l}\text { Product according to the ABNT NBR } 15,079 / 2011 \text { standard. } \\
\text { Manufacturer registered in the federal technical register of } \\
\text { potentially polluting activities }\end{array}$ \\
\hline (RDC) Differentiated Bidding Regime & $\begin{array}{l}\text { Item on Environmental and Social Sustainability in the basic } \\
\text { project, which says: The parameters defined through Norma- } \\
\text { tive Instruction 01/2010 SLTI/MPOG were observed. The } \\
\text { items provided for obtaining the environmental sustainabil- } \\
\text { ity certification, Aqua, from the Vanzolini Foundation, were } \\
\text { used. The definition of construction systems was based on } \\
\text { the use of local labour and ease of maintenance, in accord- } \\
\text { ance with art. 12, of Law 8.666/1993 }\end{array}$ \\
\hline
\end{tabular}

\subsection{Direct observation}

Here, we highlight what we observed in the daily life of the institution over a period of 12 months focused on actions and procedures aimed at sustainability. Many of the interviewees cited recycling projects, waste disposal and campaigns against waste. In various sectors, we find paper collectors for the Recycle Rural project, and in the Chemistry 
Department, oil collectors for donation. These examples were documented with photographs, which cannot be shown here. Actions aimed at sustainability will be indicated and articulated with the interviewees' statements.

...I know here at the University that a very important project that is Recycle Rural. A teacher receives disposable materials, such as paper, cardboard, ink cartridge, toner, batteries, and everything that is plastic. Recycle Rural has a partnership with an NGO. It has a Chemistry Department that collects oils. They also act together with the Research Dean's Office, which is collaborating with the Federal Government to implement the programme for the disposal and management of chemical waste produced in laboratories (Applicant 5).

Although the Recycle Rural project is well known, one of the interviewees considers it weak and comments that it should be more aggressive.

...I even believe that the University's homepage itself should have a specific area or constant calls to guide students, faculty, technicians and the entire academic community (Applicant 4).

To spread the Recycle Rural project more widely, an outsourced employee who works on this project requests the purchase of an industrial scale, an industrial shredder, also made for paper, and a shed for organizing and handling all the material collected. It was observed that the scale and the paper shredder were insufficient for the amount of paper, and the material was received at the Biology department. Increasing the collection of these materials would mean greater income for families benefiting from the Non-governmental organization (NGO), an important social work partnership with the university.

We also found posters in the corridors of the departments, with guidelines for the disposal of expired medicines, sharps and chemicals. Phones and e-mail were available to request collection. The information from the Department of Logistics and Services (Delogs) was that the university hired a company for this service because the collection of chemical waste was still low. We observed, once again, the need to carry out awareness work for greater adherence from students and teachers.

We were able to see campaigns at the University restaurant with banners against waste because the disposal of food is a concern as stated by an interviewee in this sector of the university.

...You have food residue. You do not have much of the institution's participation in this process. You have courses in gastronomy, consumer science, agronomy, and zootechnics that could be thinking together about how to improve this whole process, but it involves areas that do not communicate.

Sustainable actions sometimes require complex solutions, but the responsibility for these actions should be divided among the agents. The supplier and UFRPE could bring ideas, and the government could provide incentives or laws appropriate to the local reality. In one supplier's speech, we learned about the difficulty of this in practice.

"I recently had a meeting where I was able to present to an energy consultant to improve this issue of photovoltaic panels. So, we are interested in joining as a partner. To say: teacher, we pay the energy bill, we will finance the photovoltaic panels and put them on the roof of the restaurant. [...] but that goes through legislation. As much as he intends to do a project, I do not have the freedom to do it today. Therefore, I see the University a little stuck in the sense of being able to do more of things that they wanted" (Supplier 4). 
Thus, we emphasize again the importance of conducting training and integration between sectors and suppliers to search for sustainable solutions (Aragão \& Jabbour, 2017; Brammer \& Walker, 2011). These solutions may emerge from the dialogue between the actors involved in sustainability actions.

\section{Policy and managerial implications}

Public procurement starts to have a new conception when they adopt sustainability as a guiding criterion for its realization. The sector moves from receiving orders to being proactive, focusing on the strategic objectives of the institution. In this way, the control agency is demanding actions to avoid the waste of resources and the search for sustainability. An example is that every bidding must be preceded by a preliminary technical study, where it must be indicated whether the contract or service is in line with the institutional development plan. In this study, it is possible to identify what needs to be done beforehand, such as market survey, forecast of environmental impacts and which subsequent actions, for example, some type of civil suitability. At the end of the study, servers must declare whether the purchase or service is viable or not.

In Brazil, public policies were launched on the path of sustainability. This is the case of the Sustainable Logistics Plan (SLP) described in Normative Instruction No. 10, of November 12, 2012, of the Secretariat for Logistics and Information Technology of the Ministry of Planning, Budget and Management (Brasil, 2012). This document indicates that SLP is a planning tool-with defined objectives and responsibilities, actions, goals, execution deadlines and monitoring and evaluation mechanisms - that allows the institution or entity to establish sustainability practices and rationalize expenses and processes in the Administration Public. Many of these actions necessarily go through the purchasing sector and promote operational efficiency and cost reduction to contribute to the achievement of strategic objectives.

In this way, this work contributes to clarifying the cycle and dimensions that involve the purchasing sector. In addition, this article indicates the challenges, bottlenecks and opportunities from the point of view of stakeholders for hiring and procurement consistent with public policies. By understanding all this dynamics, it is possible to build risk management mechanisms, which will provide support for decision-making during contract management. So, the main contribution of this research was to identify how people involved with purchases (applicants, buyers and suppliers), in a Brazilian public university, understand and evaluate the requirement to adopt Sustainable Public Contracts (SPP). In addition, we see how these actors consider the relationship between ethics and sustainability. Man's action has implications for the environment and his behaviour stems from the way he conceives and values the assets of his physical and social surroundings. Therefore, identifying the way they think and evaluate the requirements of sustainable actions, in their daily work practices, constitutes a relevant step in the search for strategies to be mobilized for effective changes in Sustainable Public Contracts.

The study contributes to SPP theory and practice in four ways. First, public policies require sustainable measures through the law and to adopt them you need to know them. Second, complex solutions for adopting sustainable criteria and solutions require the union of interdisciplinary groups; in the case of UFRPE, the union of teachers, administrative technicians and suppliers is necessary. Third, COVID-19's post-pandemic world economic recession will require more than aid assistance; urgent measures are needed to improve 
people's reality — SSPs have a social concern, foster the local market and encourage buying with small companies. In addition, universities develop extension projects that can have a positive impact on community life. Fourth, the international market is more demanding on the sustainable factor; Brazil, for example, is suffering retaliation from foreign buyers to force the containment of wild fires in the Amazon rainforest. Therefore, the implications of this study point in the direction of improving the adoption of SPP in a public university in Brazil, reaching other universities with similar realities, in underdeveloped or developing countries.

Thus, the traditional simplistic view of the purchasing sector no longer fits, and it is necessary to add intelligence in management with a systemic view of the entire process. This understanding will bring gains with the efficiency of public money and the important use of market power to bring environmental and social benefits and foster a sustainable market. The State can transform the reality of different markets and impact on the fulfilment of the objective of different policies. In this way, the best proposal does not refer only to the lowest price, but the one with the best price with all the required sustainable criteria. In addition, sustainability indicators are usually presented in the management strategies of public institutions. Thus, this work contributes for the institution to have an integrated vision of SPP to better define the objectives and select, manage potential suppliers.

\section{Conclusions and scope of future works}

The case study of the Federal Rural University of Pernambuco sought to identify the main difficulties in the adoption of sustainable public procurement (SPP). The analysis of the interviews, the records from direct observations and the documents that regulate university purchases, examined as a whole, allowed us to identify difficulties inherent in sustainable purchases for the university. This process represents an important step in a proposal that will be suggested for more controlled and sustainable ways of maintaining the institution and an ethical commitment to the use of public money. Therein lies the relevance of the present contribution. When articulating the information collected in difference ways, and therefore, seeking more from the analyses, we approach the current meanings that are at the base of the institutional microculture. However, this is a case study of a public institution of higher education. It is not possible to generalize these findings to other universities, even if they share common aspects, such as documents regulating public service purchases. This issue is a limitation of the present study. The meanings are being constructed in purchasing practices, in the way the institution equates its decisions, in the understanding and involvement of the actors in this process, and in the way the market itself is formulating its laws and controls for profit.

This research has other limitations that can be extended as guidelines for future work in this area. In this work, a group of suppliers that provide services to the university was selected. A study with a set of activities from different suppliers can contribute to understanding more about the main difficulties for companies to adopt sustainable criteria. Another research suggestion would be to extend the investigation to another public university, located in the same state of Pernambuco and with a reality very close to UFRPE, in order to know how sustainability practices that are acquired in this second institution and, thus, consolidate a more comprehensive understanding distributed than was found here.

In this study, it was found that in general, servers and suppliers have notions of sustainability and SPP in addition to giving importance to the theme. These groups understand that 
ethics are directly related to the practice of sustainability, but it is a difficult issue because it involves historical roots and changes in paradigms. Due to the complexity of the SPP theme, one of the main implementation difficulties is the scarcity of training and discussion between university sectors and suppliers. The lack of a market prepared for sustainability was a consensus. A deficient culture of sustainability, unfavourable economic policy and misalignment between public administration and businessmen are the reasons for this lack of market for suppliers. They have the idea that UFRPE is committed to adopting sustainable practices but is limited by legal and governmental oversight.

As we can see in this research, sustainable practices demand concern for others. Voluntary actions are important to develop a sense of social responsibility and behavioural change. One suggestion would be to provide tutoring classes for students from public schools in the community. Another suggestion would be to publicize actions that already occur at UFRPE but of which not everyone is aware. One example is the case of the professor who managed to maintain the microscopes correctly and improved their use. Rewarding good ideas and actions contributes to motivating and propagating sustainability.

The university involves people, knowledge and components of transformation. It is necessary to unite and improve this environment. In this context, sustainable public procurement can serve as a tool to work on educational, conscious and ethical consumption. These tools are important but needy elements in an underdeveloped country, such as Brazil.

Acknowledgements We would like to acknowledge the UFRPE for supporting this work. The authors are deeply grateful to teachers Maria Isabel Pedrosa and Rejane Markmam for their detailed and insightful comments in the revision of the manuscript and to the teacher João Marcos Patrício de Carvalho for the first English review. The authors also thank the anonymous reviewers for their very helpful suggestions and comments on an earlier version of this manuscript.

\section{Declarations}

Conflict of interest The authors declare that they have no conflict of interest.

\section{References}

Agyepong, A. O., \& Nhamo, G. (2017). Green procurement in South Africa: Perspectives on legislative provisions in metropolitan municipalities. Environment, development and sustainability, 19(6), 24572474. https://doi.org/10.1007/s10668-016-9865-9.

Ahmed, S. U., Ali, A., Memon, A. H., \& Hussain, A. (2020). Policy framework for implementation of sustainable procurement practices in healthcare industry. Environment, Development and Sustainability: A Multidisciplinary Approach to the Theory and Practice of Sustainable Development. https://doi.org/10. 1007/s10668-020-00750-w.

Ahsan, K., \& Rahman, S. (2017). Green public procurement implementation challenges in Australian public healthcare sector,. Journal of Cleaner Production ISSN, 152, 181-197. https://doi.org/10.1016/j.jclep ro.2017.03.055.

Aleixo, A. M., Azeiteiro, U., \& Leal, S. (2018). The implementation of sustainability practices in Portuguese higher education institutions. International Journal of Sustainability in Higher Education, 19(1), 146-178. https://doi.org/10.1108/IJSHE-02-2017-0016.

Alencastro, M., Silva, E., \& Lopes, A. (2014a). Contratações sustentáveis na administração pública brasileira: a experiência do poder executivo federal. Revista de Administração Pública, 48(1), 207-236.

Aragão, C., \& Jabbour, C. (2017). Green training for sustainable procurement? Insights from the Brazilian public sector. Industrial and Commercial Training, 49(1), 48-54. https://doi.org/10.1108/ ICT-07-2016-0043.

Aydin, N. (2017). Spirituality and subjective wellbeing: Living a fulfilled life without falling into the trap of consumer culture. Humanomics, 33(3), 300-314. https://doi.org/10.1108/H-03-2017-0052. 
Barron, K., \& Chou, S. (2017). Toward a spirituality mode of firm sustainability strategic planning processes. Society and Business Review, 12(1), 46-62. https://doi.org/10.1108/SBR-01-2016-0008.

Batista, M., \& Maldonado, J. (2008). O papel do comprador no processo de compras em instituições públicas de ciência e tecnologia em saúde (C\&T/S). Revista de Administração Pública, v. 42, n. 4, (p. 681700), jan. ISSN 1982-3134. http://bibliotecadigital.fgv.br/ojs/index.php/rap/article/view/6650.

Biderman et al. (Org) (2008). Guia de compras públicas sustentáveis. Uso do poder de compra do governo para a promoção do desenvolvimento sustentável. São Paulo: ICLEI European Secretariat. Accessed 3 May 2018 from https://www.mma.gov.br/estruturas/a3p/_arquivos/guia_compras_sustentaveis.pdf.

Biedenweg, K., Monroe, M., \& Oxarart, A. (2013). The importance of teaching ethics of sustainability. International Journal of Sustainability in Higher Education, 14(1), 6-14. https://doi.org/10.1108/ 14676371311288912.

Boff, Leonardo (2006). Ética e Sustentabilidade. Caderno de Debate Agenda 21 e Sustentabilidade. $2^{\text {a }}$ Edição.

Brammer, S., \& Walker, H. (2011). Sustainable procurement in the public sector: An international comparative study. International Journal of Operations and Production Management, 31(4), 452-476. https:// doi.org/10.1108/01443571111119551.

Brasil. (2012). Ministério do Planejamento, Orçamento e Gestão. Instrução Normativa $n^{\circ} 10$, de 12 de novembro de 2012, https://www.gov.br/compras/pt-br/acesso-a-informacao/legislacao/instrucoesnormativas/instrucao-normativa-no-10-de-12-de-novembro-de-2012

Brasília: MMA, 15p. Accessed 3 May 2018 from http://www.mma.gov.br/estruturas/agenda21/_arquivos/ CadernodeDebates10.pdf.

Camargo, S., \& Pinheiro, A. (2010). Fundamentação ética do desenvolvimento sustentável em kant, habermas e hansjonas. Revista do Direito Público, 5(2), 177-193. https://doi.org/10.5433/1980-511X.2010v $5 \mathrm{n} 2 \mathrm{p} 177$.

Capello, M., \& García Oro, L. G. (2015). Gasto público eficiente: Propuestas para un mejoramiento em los sistemas de compras y contrataciones gubernamentales. Actualidad Económica, v. 25, n. 85, p. 5-20, 2015. ISSN 2250-754X. https://revistas.unc.edu.ar/index.php/acteconomica/article/view/11843.

Cardoso, J. (2016). Contratações públicas sustentáveis: da teoria à prática. Brasília: Enap, 2016. (p.127) https://comunidades.enap.gov.br/ram/compras/pdf/licitacoes-sustentaveis/contratacoes-publicas.pdf. Accessed 3 May 2018.

Carmo, B., Margni, M., \& Baptiste, P. (2018). Propagating uncertainty in life cycle sustainability assessment into decision-making problems a multiple criteria decision aid approach. In E. Benetto, K. Gericke, \& M. Guiton (Eds.), Designing sustainable technologies, products and policies. Cham: Springer.

Cooper, D., \& Schindler, P. (2016). Métodos de Pesquisa em Administração - a Edição. . New York: McGraw Hill Brasil.

Cortese, A. D. (2003). The critical role of higher education in creating a sustainable future. Planning for higher education, 31(3), 15-22.

Couto, H., \& Coelho, C. (2015). Fatores críticos no comportamento do gestor público responsável por compras sustentáveis: Diferenças entre consumo individual e organizacional. Revista de Administração Pública-RAP. https://doi.org/10.1590/0034-7612113443.

Couto, H., \& Ribeiro, F. (2016). Objetivos e desafios da política de compras públicas sustentáveis no Brasil: A opinião dos especialistas. Revista de Administração Pública, 50(2), 331-343. https://doi.org/10. 1590/0034-7612146561.

Dolabela, F. (2004). Pedagogia empreendedora. Revista de Negócios, 9(2), 2004. https://doi.org/10.7867/ 1980-4431.2004v9n2p\%25p.

Editorial (1993) Individualismo e ética. Perspectiva Teológica, vol. 25, n. 67, p. 275-278. Editorial.. Accessed 3 fev 2018 from https://faje.edu.br/periodicos/index.php/perspectiva/article/view/1455/1823.

El-Zein, A., Airey, D., Bowden, P., \& Clarkeburn, H. (2008). Sustainability and ethics as decision-making paradigms in engineering curricula. International Journal of Sustainability in Higher Education, 9(2), 170-182. https://doi.org/10.1108/14676370810856314.

Emanuel, R., \& Adams, J. N. (2011). College students' perceptions of campus sustainability. International Journal of Sustainability in Higher Education, 12(1), 79-92. https://doi.org/10.1108/1467637111 1098320 .

Alencastro, M. A. C., Silva, E. V., \& da. (2014b). Contratações sustentáveis na administração pública brasileira: a experiência do Poder Executivo federal. Revista de Administração Pública, 48(1), 207-236. https://doi.org/10.1590/S0034-76122014000100009.

Faria, J. (2014). Por uma teoria crítica da sustentabilidade. Organizações e Sustentabilidade, v. 2, n. 1, p. 2-25, http://www.uel.br/revistas/uel/index.php/ros/article/view/17796/15172 . Accessed 5 abr 2018. 
Fleck, A. (2017). Afinal de contas, o que é teoria crítica? After all, what is critical theory? Princípios: Revista de Filosofia (UFRN), 24(44), 97-127. https://doi.org/10.21680/1983-2109.2017v24n44 ID12083.

Freitag, B. (1994). A teoria crítica: ontem e hoje. São Paulo: Brasiliense, 2004. https://faje.edu.br/perio dicos/index.php/perspectiva/article/view/1455/1823. Accessed 3 Feb 2018.

Furtado, C. (1974). O mito do desenvolvimento econômico. . Paz e Terra.

Gimenez, C., Sierra, V., \& Rodon, J. (2012). Sustainable operations: Their impact on the triple bottom line. International Journal of Production Economics, 140(1), 149-159. https://doi.org/10.1016/j. ijpe.2012.01.035.

Guiton, M., \& Benetto, E. (2018). Special session on product environmental footprint. In E. Benetto, K. Gericke, \& M. Guiton (Eds.), Designing sustainable technologies, products and policies. Cham: Springer.

Howard, A. (2010). A new global ethic. Journal of Management Development, 29(5), 506-517. https:// doi.org/10.1108/02621711011039259.

Hunting, A., \& Conroy, D. (2018). Espiritualidade, gestão e consumo: novas formas de viver em um mundo material. Jornal de Responsabilidade Social, 14(2), 255-273. https://doi.org/10.1108/ SRJ-06-2016-0097.

Iclei (2015). Manual Procura+ Um Guia para Implementação de Compras Públicas Sustentáveis. $3^{\mathrm{a}}$ ed. São Paulo. http://e-lib.iclei.org/wp-content/uploads/2018/10/Manual_Procura_BR_final.pdf. Accessed 3 May 2018.

Imperatives, S. (1987). Report of the World Commission on Environment and Development: Our common future. http://www.ask-force.org/web/Sustainability/Brundtland-Our-Common-Future-1987-2008.pdf. Accessed 2 Jun 2018.

Kaur, H., \& Singh, S. P. (2019). Sustainable procurement and logistics for disaster resilient supply chain. Annals of Operations Research, 283(1), 309-354. https://doi.org/10.1007/s10479-016-2374-2.

Kibert, C.J, Thiele, L., Peterson, A. \& Monroe, M. (2011). The Ethics of Sustainability, John Wiley \& Sons Ltd, UK. http://rio20.net/wp-content/uploads/2012/01/Ethics-of-Sustainability-Textbook.pdf.

La Taille, Y., Souza, L., \& Vizioli, L. (2004). Ética e educação: uma revisão da literatura educacional de 1990 a 2003. Educação e Pesquisa, São Paulo, 30(1), 91-108. https://doi.org/10.1590/S151797022004000100006.

Leal Filho, W., Skouloudis, A., Brandli, L. L., Salvia, A. L., Avila, L. V., \& Rayman-Bacchus, L. (2019). Sustainability and procurement practices in higher education institutions: Barriers and drivers. Journal of cleaner production, 231, 1267-1280. https://doi.org/10.1016/j.jclepro.2019.05.202.

Lehtinen, U. (2012). Sustainability and local food procurement: a case study of Finnish public catering. British Food Journal, 114(8), 1053-1071. https://doi.org/10.1108/00070701211252048.

Llatas, M. V., \& da Silva Júnior, W. J. (2005). Algumas reflexões sobre ética nas organizações. Revista Organizações em Contexto, 1(2), 9-24. https://www.metodista.br/revistas/revistasims/index.php/ OC/article/view/1250/1265

Mattos, P. (2005). A entrevista não-estruturada como forma de conversação: Razões e sugestões para sua análise. Revista de Administração Pública - RAP, v. 39, n. 4. Rio de Janeiro, v. 39, n. 4, p. 823 a 848, jan. 2005. ISSN1982-3134. http://bibliotecadigital.fgv.br/ojs/index.php/rap/article/view/6789. Accessed 3 fev 2018.

Neto, B., \& Caldas, M. G. (2018). The use of green criteria in the public procurement of food products and catering services: a review of EU schemes. Environment, development and sustainability, 20(5), 1905-1933. https://doi.org/10.1007/s10668-017-9992-y.

O’Hara, S. (1998). Economics, ethics and sustainability: redefining connections. International Journal of Social, Economics, 25(1), 43-62. https://doi.org/10.1108/03068299810194893.

ONU (2017). Banco Mundial: serão necessários 3 planetas para manter atual estilo de vida da humanidade. https://nacoesunidas.org/banco-mundial-serao-necessarios-3-planetas-para-manter-atualestilo-de-vida-dahumanidade. Accessed 21 May 2017.

Pacheco-Blanco, B., \& Bastante-Ceca, M. (2016). Green public procurement as an initiative for sustainable consumption. An exploratory study of Spanish public universities. Journal of Cleaner Production, 133, 648-656. https://doi.org/10.1016/j.jclepro.2016.05.056.

Pedron, A. P. B., Macagnan, C. B., \& Simon, D. S. (2020). Environmental disclosure effects on returns and market value. Environment, Development and Sustainability, . https://doi.org/10.1007/ s10668-020-00790-2.

Rajesh, R., \& Rajendran, C. (2020). Relating environmental, social, and governance scores and sustainability performances of firms: An empirical analysis. Business Strategy and the Environment, 29(3), 1247-1267. https://doi.org/10.1002/bse.2429. 
Rajesh, R. (2020). Exploring the sustainability performances of firms using environmental, social, and governance scores. Journal of Cleaner Production, 247, 119600. https://doi.org/10.1016/j.jclepro.2019. 119600.

Ramos, P., \& Santos, C. (2017). Licitações públicas sustentáveis: um estudo no Instituto Federal de Educação, Ciência e Tecnologia do Rio Grande do Sul. In: Encontro internacional sobre gestão ambiental e meio ambiente (ENGEMA), 19. São Paulo. Anais SP: ISSN 2359-1048, 2017. p. 1 - 16.http://engem ausp.submissao.com.br/19/anais/arquivos/259.pdf. Accessed 26 May 2018.

Raymond, J. (2008). Benchmarking in public procurement. Benchmarking: An International Journal, 15(6), 782-793. https://doi.org/10.1108/14635770810915940.

Rodriguez-Rad, C., \& Ramos-Hidalgo, E. (2018). Spirituality, consumer ethics, and sustainability: the mediating role of moral identity. Journal of Consumer Marketing, 35(1), 51-63. https://doi.org/10. 1108/JCM-12-2016-2035.

Sachs, I. (2009). Caminhos para o desenvolvimento sustentável. . Editora Garamond.

Sampieri, R., Callado, C., \& Lucio, M. (2013). Metodologia da Pesquisa. (5th ed., p. 624). Penso.

Shephard, K. (2008). Higher education for sustainability: seeking affective learning outcomes. International Journal of Sustainability in Higher Education, 9(1), 87-98. https://doi.org/10.1108/146763708108422 01 .

Testa, F., Annunziata, E., Iraldo, F., \& Frey, M. (2016a). Drawbacks and opportunities of green public procurement: An effective tool for sustainable production, . Journal of Cleaner Production, 112, 18931900. https://doi.org/10.1016/j.jclepro.2014.09.092.

Testa, F., Grappio, P., Gusmerotti, N. M., Iraldo, F., \& Frey, M. (2016b). Examining green public procurement using content analysis: existing difficulties for procurers and useful recommendations. Environment, development and sustainability, 18(1), 197-219. https://doi.org/10.1007/s10668-015-9634-1.

Tokbolat, S., Karaca, F., Durdyev, S., \& Calay, R. K. (2019). Construction professionals' perspectives on drivers and barriers of sustainable construction. Environment, Development and Sustainability. https:// doi.org/10.1007/s10668-019-00388-3.

UFRPE (2018). Plano de Desenvolvimento Institucional. UFRPE 2013 - 2020. http://www.ead.ufrpe.br/ sites/www.ead.ufrpe.br/files/Cursos-Info/LF/PDI\%20UFRPE\%202013-2020_v2.pdf. Accessed 2 Jun 2018.

UNDP (2019), Human Development Report 2019.United Nations Development Programme (UNDP).

Velazquez, L., Munguia, N., \& Sanchez, M. (2005). Deterring sustainability in higher education institutions: An appraisal of the factors which influence sustainability in higher education institutions. International Journal of Sustainability in Higher Education, 6(4), 383-391. https://doi.org/10.1108/1467637051 0623865.

Walker, H., \& Brammer, S. (2012). The relationship between sustainable procurement and e-procurement in the public sector. International Journal of Production Economics, 140(1), 256-268. https://doi.org/10. 1016/j.ijpe.2012.01.008.

Warken, I., Henn, V., \& da Rosa, F. (2014). Gestão da sustentabilidade: Um estudo sobre o nível de sustentabilidade socioambiental de uma Instituição Federal de Ensino Superior. Revista de Gestão, Finanças e Contabilidade, 4(3), 147.

Weisser, C. (2017). Defining sustainability in higher education: a rhetorical analysis. International Journal of Sustainability in Higher Education, 18(7), 1076-1089. https://doi.org/10.1108/ IJSHE-12-2015-0215.

Yang, Z., Sun, J., Zhang, Y., \& Wang, Y. (2020). Synergy between green supply chain management and green information systems on corporate sustainability: An informal alignment perspective. Environment, Development and Sustainability, 22(2), 1165-1186. https://doi.org/10.1007/s10668-018-0241-9.

Yin, R. (2015). Estudo de caso: Planejamento e métodos. (5th ed.). Bookman.

Zaidi, S. A. H., Mirza, F. M., Hou, F., \& Ashraf, R. U. (2019). Addressing the sustainable development through sustainable procurement: What factors resist the implementation of sustainable procurement in Pakistan? Socio-Economic Planning Sciences, 68, 100671. https://doi.org/10.1016/j.seps.2018.11.008.

Publisher's Note Springer Nature remains neutral with regard to jurisdictional claims in published maps and institutional affiliations. 


\section{Authors and Affiliations}

\section{Renata C. A. Mendonça ${ }^{1}\left(\mathbb{D} \cdot\right.$ Ivo V. Pedrosa $^{2}\left(\mathbb{D} \cdot\right.$ Maria Amália O. A. Camara $^{3}$}

Ivo V. Pedrosa

ivovpedrosa@gmail.com

Maria Amália O. A. Camara

amalia.camara@upe.br

1 Universidade Federal Rural de Pernambuco (UFRPE), Rua Dom Manuel de Medeiros, s/n-Dois Irmãos, Recife, PE 52171-900, Brasil

2 Universidade de Pernambuco (UPE), Rua Casa Forte, Casa Forte, 65, apartamento, 1101, Casa Forte, Recife, PE 52061-460, Brasil

3 Universidade de Pernambuco (UPE), Avenida Sport Clube do Recife, 252-Madalena, Recife, PE 50750-500, Brasil 